\title{
The Determinants of Cost/Profit Efficiency of Islamic Banks Before, During and After the Subprime Crisis Using SFA Approach
}

\author{
Asma Mghaieth \\ University of Manouba , LARIME Lab (Tunis- Tunisia) \\ asmamghaieth@live.fr \\ Imen khanchel \\ University of Manouba , LARIME Lab (Tunis- Tunisia) \\ im_khanchel@yahoo.fr
}

DOI: 10.5296/ijafr.v5i2.7866 URL: http://dx.doi.org/10.5296/ ijafr.v5i2.7866

\begin{abstract}
In this paper we estimate the determinants of cost and profit efficiency of Islamic banks using the stochastic frontier approach SFA. We use 62 Islamic banks in sixteen countries of the MENA and South-East Asia regions during the period 2004-2010. We compare the efficiency between Islamic banks during the subprime crisis phases. Moreover, we examine the variables specific to the banks which can explain the sources of inefficiency and those let us decline the scores of cost and profit efficiency on a specific number of variables (total assets, capital adequacy, profitability, credit risk, operational costs). Results reveal that, Islamic banks in our study are more efficient in the generation of the profits rather than in the control of the costs. Thus, only the total assets and the operational costs represent the determinants of cost efficiency of the Islamic banks. Finally, for the profit efficiency our results indicate that the Islamic banks with high equities and high ratio of profitability are efficient in terms of profit.
\end{abstract}

Keywords: Islamic Banks, SFA, Cost Efficiency, Profit Efficiency, Equity

\section{Introduction}

During the last two decades, a particular interest was granted to the Islamic banking system. A deep and broad desire to understand this system emerged in almost all regions of the world. Islamic banks are led to improve their efficiency and to develop their performance to maintain sustainability. Thus, the estimation for efficiency became both complex and compulsory demanding more flexible alternative forms, more flexible formal analysis of efficiency and more quantitative research techniques.

In this study we examine the determinants of cost and profit efficiencies in the MENA and Southeast Asia regions. Our study differs from the existing literature in several points. First of all, we use a large number of Islamic banks (62 banks). We cover a wide range of countries (16 countries) and we extend our study to cover a longer period going from 2004 to 2010 
(before, during and after the 2008 financial crisis). In addition, to estimate frontier functions of cost and profit, we introduce specific variables to each country (macroeconomic variables). Therefore, we take into account the variation in the banking technologies which can be linked to macroeconomic conditions and the structure of banking from a country to another. We also compare scores of cost and profit efficiencies per country. These scores attempts to identify possible factors explaining the observed differences of cost and profit efficiencies for banks in countries of MENA and Southeast Asia.

Even if the review of the literature examining the determinants of Bank efficiency is concentrated in the European and American markets, work on Islamic finance is still at its beginning. Generally, studies on the efficiency of Islamic banks have focused on theoretical issues and empirical works have been based mainly on the analysis of descriptive statistics rather than the statistical estimation. However, some recent studies tried to apply the different techniques of frontiers to assess the efficiency of Islamic banks. We need to point out that researchers in Islamic finance consider the same appropriate conventional criteria to measure the performance of Islamic banks.

The remainder of the paper is structured as follows: Section 2 discusses hypothesis and methodology. The data and the preliminary analysis are displayed in Section 3 while Section 4 displays and discusses the empirical results. Finally, Section 5 reports the summary and concluding remarks of the study.

Literature on the frontier of production and the calculation of the efficiency measures began with Debreu (1951) and Farrell (1957). In 1957, Farrell has shown that the efficiency of the firm can be empirically calculated and proposes, for the first time, a radical method of estimation of the efficiency frontier from the observation of the real production situations.

In theoretical studies on the efficiency of banking institutions, several methods have been adopted. However, it is necessary to estimate the determinants of the efficiency of the banks to specify a functional form that allows both to describe the production process and to take into account all the variables that can influence this process. This explains the adoption of the SFA approach in our measure of efficiency of Islamic banks. The residue, which is not explained by the model, is considered as inefficiency.

Berger and Mester (1997) argue that the parametric technique SFA provides more useful results than non-parametric techniques because they are based on economic optimization rather than technical optimization. The alternative technique non parametric and the most popular is data envelopment analysis (DEA). This method requires no assumptions concerning the shape of the frontier, but it gives similar estimates of economies of scale as the ones obtained from parametric techniques. Since it does not require data on prices, most studies of DEA focus only on technical efficiency, even if it can be extended to also examine the allocative efficiency.

Researches dealing with the Islamic banks have emerged over the two last decades, but they are very limited in number and statistical depth given the recent nature of these banks. These studies can be divided into 2 groups. The first group calculates scores of cost and profit efficiency using the SFA. Some researches calculate only scores of cost efficiency: Staikouras et al. (2008), Koutsomanoli-Filippaki et al. (2009) and Fries and Taci (2005). Somme studies calculates both scores of cost and profit efficiency: Berger and Mester (1997) 


\section{Ml Macrothink}

International Journal of Accounting and Financial Reporting

ISSN 2162-3082

2015, Vol. 5, No. 2

and Yildirim and Philippatos (2007). For Islamic finance-specific efficiency studies, some studies found showing high level of profit efficiency compared to that of cost efficiency like Hassan (2005) for a sample of Islamic banks. Olson and Zoubi (2008) have found a great profitability of Islamic banks as compared to those conventional. Among research showing that Islamic banks are more efficient in controlling costs than in generating profits, we have Kamaruddin et al. (2008), Hassan and Hussein (2003) examined. Others research (James and Svein, 2012; Mariani, 2011; Michael et al., 2013) calculated the levels of scores of cost and profit efficiencies with parametric and non-parametric approaches.

A second group of studies concentrates on the researches dealing with the determinants of efficiency. Some studies attempts to examine the determinants of profit efficiency. The Results of Bashir (1999) show that measures of profit efficiency of Islamic banks increases with capital and loans ratios. Later, Bashir (2003) conducted regression to find that the profitability of banks is mainly determined by overheads and short term financing. Hassan and Bashir (2003) studied the effects of controlled and uncontrolled variables on the profitability of Islamic banks and they have shown that some economic variables, such as capital and gross domestic product, were positively correlated with profitability. However, credits, taxes and the size of the reserve ratios, have a negative impact on the profitability of the Islamic Bank. Haron (2004) shows a significant relation between the profitability of Islamic banks and the structure of their assets. The results of panel data have shown a significant and positive relation between the internal Islamic banks profitability measures and its determinants such as liquidity, the structure of assets, total spending, inflation and money supply which must be closely monitored by officials of the Bank. The same relation was detected for external factors such as the interest rate, market share and the size of the Bank. As for both the market share and the money supply, there is an adverse effect on profits. Zarrouk (2012) using a modeling data panel to estimate profitability ratios, liquidity, risk, solvency and efficiency ratio. She found that large-sized banks display a better performance than their counterparts in small size which is due to the economies of scale, the broader diversification and a better reputation. Moreover, ROA and ROE ratios have also decreased. Although, Teng et al. (2012) have not found a significant relation between the ratio of capital and profitability of the Bank, a positive relation between the size of the bank and profitability explained by the economy of scale has been found. Results of this study show also no significant relation between GDP and profitability which contradicts the results of Abdul et al. (2013) who have found a positive relationship between GDP and profitability of Islamic banks. Olson and Zoubi (2011) try to find determinants of the efficiency of the banks in the MENA region during the period 2000-2008. They show that most of the banks in this region are smaller than the optimal size and they find a positive relation between the efficiency and the total assets of a bank. They also have found a positive relation between efficiency and the capitalization ratio (EQAS). Therefore it is possible for banks to be over-capitalized. In addition, credit risk (LOAS) should positively affect efficiency as long as the Bank does not take a degree of unacceptable risk. Finally, the operational costs (COIN) are negatively correlated with the efficiency.

Other studies have only provides an analysis of the determinants of cost efficiency. Hussein (2003) found that smaller banks in Sudan are more efficient than their larger counterparts. He 


\section{Mll Macrothink}

International Journal of Accounting and Financial Reporting

ISSN 2162-3082

2015, Vol. 5, No. 2

found a positive relationship between the ratio of capital adequacy and cost efficiency. Ben Khediri et al. (2009) show a negative relationship between the operating costs of Islamic banks in Africa and cost efficiency. Moreover, Ben Khediri et al. (2009) find that the efficiency of a bank is positively associated with economic growth. Burki and Ahmad (2011) examined the efficiency and performance of the banking system in Pakistan. Hassan and Hussein (2003) examined the efficiency of the Sudanese banking system during the period 1992-2000. They found that cost inefficiency of Islamic banks was mainly due to technical factors (related to management) rather than the factors of resource allocation (regulatory). Later, Hassan (2006) examined the cost and profit efficiencies of the banking industry in the Islamic world. Using a panel of banks during the period 1993-2001, he found that Islamic banks are more efficient in the generation of profits. The results show that the ROA ratio is strongly correlated with efficiency, suggesting that this ratio can be used in computing the efficiency of Islamic banks.

\section{2- Methodology}

\section{1- Efficiency scores}

In accordance with recent developments in literature (Fries and Taci 2005; Pereraet al. 2007; Mamatzakiset al. 2008; Srairi, 2010) and in order to capture the heterogeneity among countries, the cost in this study function is extended to adapt to country-specific variables:

Where

$$
\mathbf{T C}_{\mathrm{ijt}}=\mathbf{f}\left(\mathbf{P}_{\mathrm{ijt}}, \mathbf{Y}_{\mathrm{ijt}}, \mathbf{E}_{\mathrm{ijt}}\right)+\varepsilon_{\mathrm{ijt}}
$$

- TC : total cost

- P : vector of outputs

- $\quad \mathbf{Y}$ : vector of prices of inputs

- $\mathbf{E}$ : vector of country-specific variables

- $\boldsymbol{\varepsilon}_{\mathrm{ijt}}=\mathbf{V}_{\mathrm{ijt}}+\mathbf{U}_{\mathrm{ijt}}$ : terms of inefficiencies corresponding to the random fluctuations.

With $\mathbf{V}_{\mathrm{ijt}} \mathbf{i i d} \sim \mathbf{N}\left(\mathbf{0}, \boldsymbol{\sigma}_{\mathrm{v}}^{\mathbf{2}}\right)$

$\mathbf{U}_{\mathrm{ijt}} \sim \mathbf{1 / 2 N}\left(\mathbf{u}, \boldsymbol{\sigma}^{2}{ }_{\mathbf{u}}\right)$ : half normal distribution that captures the effects of inefficiency.

This approach assumes that the total cost differs from the optimal cost by random distribution $\mathbf{V}_{\mathbf{i j t}}$ and the inefficiency terms $\mathbf{U}_{\mathbf{i j t}}$ and $\mathbf{V}_{\mathbf{i j t}}$ correspond to random fluctuations. These are two figures in terms of classical statistical terms of errors which constitute the effects of errors in the measurement of the explanatory variables.

The General procedure adopted in this study is to estimate the coefficients and the error of equation (II.1) and to calculate the scores efficiency of each bank in the sample. The cost frontier can be estimated by maximum likelihood method and the level of efficiency is estimated through the use of regression of the error terms.

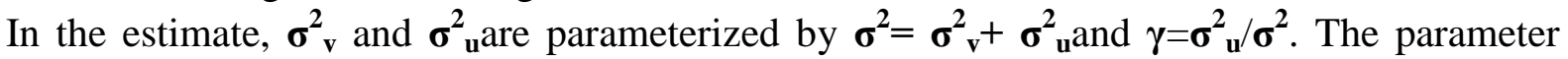
$\mathbf{0}<\boldsymbol{\gamma}<\mathbf{1}$; If it is close to 0 that is a small inefficiency exists and the model can be estimated systematically through the use of the method of ordinary least squares. However, a large value of yimplies a deterministic frontier (coelli, 1996). 


\section{Macrothink}

International Journal of Accounting and Financial Reporting

ISSN 2162-3082 2015, Vol. 5, No. 2

The measurement of cost efficiency of any bank in time $(\mathrm{t})$ is calculated by the frontier estimated as $\mathbf{C E}_{\mathbf{i t}}=\mathbf{1 / \mathbf { e x p }}\left(\mathbf{U}_{\mathbf{i t}}\right)$. This measure takes the value between 0 and 1 . Banks with scores close to 1 are the most efficient.

In order to identify the factors that are correlated with the inefficiency of the banks we use the model of Battese and Coelli (1995) which allows studying the determinants of inefficiency (equation II.2). Specifically, $U$ is supposed to be a series of functions of characteristics specific to the banks.

In order to present the inefficiency, we use the following auxiliary model:

$$
\mathbf{U}_{\mathrm{ijt}}=\partial \mathbf{Z}_{\mathrm{ijt}}+\mathbf{W}_{\mathrm{ijt}}(\mathbf{I I . 2})
$$

Where:

- $\mathbf{Z}$ : vector of explanatory variables specific to banks.

- W: random variable that has a normal distribution $\left(\mathrm{W}_{\mathrm{ijt}} \sim \mathrm{N}\left(0, \sigma^{2}{ }_{\mathrm{w}}\right)\right)$.

- $\partial$ : vector of unknown to estimate parameters.

For our cost function, we choose the Trans log specification. According to Greene (1980), this function is the model selected most frequently used to measure the efficiency of banks, because it represents known benefits. It is a flexible functional form. In addition it includes as a special case the Cobb-Douglas (Carvalo and Kasman, 2005) specification.

The Trans log stochastic cost function takes the form of the equation (II.3):

$$
\begin{aligned}
& \ln \mathbf{T C}_{\mathrm{ijt}}=\alpha_{0}+\sum_{m=1}^{3} \alpha_{\mathrm{m}} \ln \mathbf{Y}_{\mathrm{m}, i j t}+\sum_{s=1}^{2} \beta_{\mathrm{s}} \ln \mathbf{P}_{\mathrm{s}, i j t}+\mathbf{l}_{1} \mathrm{~T}+\sum_{l=1}^{8} \rho_{l} \ln \mathrm{E}_{i j t} \\
& +1 / 2\left[\sum_{m=1}^{3} \sum_{n=1}^{3} \alpha_{m_{s}, \mathrm{n}} \ln Y_{\mathrm{m}, i j t} * \ln Y_{n, i j t}+\sum_{s=1}^{2} \sum_{r=1}^{2} \beta_{s, \mathbf{r}} \ln \mathbf{P}_{s, i j t} * \ln P_{r, i j t}+\mathbf{l}_{2} T^{2}\right] \\
& +\sum_{m=1}^{3} \sum_{s=1}^{2} \phi_{m_{s} s} \ln Y_{m, i j t} * \ln P_{s, i j t}+\sum_{m=1}^{3} \lambda_{m} T \ln Y_{m, i j t}+\sum_{s=1}^{2} \Psi_{s} T \ln P_{s_{i} \mathrm{ijt}}+\varepsilon .
\end{aligned}
$$

With:

- i: means banks $(i=1 \rightarrow 62)$.

- $\mathbf{j}$ : designates countries $(\mathrm{j}=1 \rightarrow 16)$.

- $\mathbf{t}$ : time horizon $(\mathrm{t}=2004 \rightarrow 2010)$.

- InTC: normal log of total costs.

- $\ln \mathbf{Y}_{\mathbf{m}}$ : normal $\log$ of the inputs price.

- $\ln \mathbf{P}_{\mathbf{s}}$ : normal $\log$ of the outputs values.

- E : natural environmental variables in log vector.

- T: time trend variable used to capture the technical changes.

- $\boldsymbol{\alpha}, \boldsymbol{\beta}, \mathbf{l}, \boldsymbol{\rho}, \boldsymbol{\Phi}, \lambda$ and $\psi$ : parameters to be estimated. 
- $\varepsilon$ : composite error term.

To ensure that the estimated cost frontier behaves well, Fries and Taci (2005) have imposed constraints of:

$$
\begin{aligned}
& \quad \checkmark \text { Symmetry : : } \boldsymbol{\alpha}_{m_{i} n}=\boldsymbol{\alpha}_{n_{i} m} \text { for all m, n } \\
& \boldsymbol{\beta}_{s_{i} r}=\boldsymbol{\beta}_{r_{s} s} \text { for all s, } \mathrm{r}
\end{aligned}
$$

$\checkmark$ Homogeneity of prices: $\sum_{m=1}^{2} \alpha_{m}=1$;

$$
\sum_{m}^{n} \alpha_{\mathbf{m}_{2} \mathbf{n}}=\sum_{m}^{s} \boldsymbol{\phi}_{\mathbf{m}_{s} s}=\sum_{m}^{2} \lambda_{m}=\mathbf{0}
$$

However, most of the parametric models applied to financial institutions were interested in the study of the cost efficiency. Thus, we could pick up these last years a certain resurgence of interest for efficiency advantage (Isik and Hassan, 2002; Al-Jarrah and Molyneux, 2003; Mohamed and Molyneux, 2003; Srairi, 2010).

This concept requires that the Manager should not only pay attention to the reduction of the marginal dollar of costs, but also to the increase in the marginal dollar of revenue. Our approach, according to Pulley and Humphrey (1993) and Berger et al. (1997) is based on the assumption that firms have some market power in the pricing of outputs.

Berger and Mester (1997) propose to distinguish between two types of profit efficiency: the standard profit efficiency and the alternative profit efficiency.

Here, we choose the alternative profit efficiency (APE) which takes the quantities of outputs as data instead of the price of outputs. This approach incorporates the differences between banks in market power and their capacity to exploit them (Dietsh and Weill, 1997).

In the calculation, we use the same form trans log cost function, and total cost in the equation (II.3) are replaced with the total profit before taxes. To avoid log numbers negative we transformed the variable profit by the formula $\ln (\boldsymbol{\pi}+\boldsymbol{\theta}+\mathbf{1})$.

Where $\boldsymbol{\theta}$ : absolute value of the min of profit $(\pi)$ of all banks of the sample.

Thus, for the Bank with the lowest annual profit, the dependent variable of the profit function is going to be equal to $\ln (1)=0$.

Also, to measure the efficiency under the profit function scores the composite error is:

$$
\boldsymbol{\varepsilon}=\mathbf{V}_{\mathbf{i}}-\mathbf{U}_{\mathbf{i}}
$$

The measurement of profit efficiency is defined as:

$$
\mathbf{P E}_{\mathrm{it}}=\exp \left(-\mathrm{U}_{\mathrm{it}}\right)
$$

In this case, the efficiency scores take a value between 0 and 1 with values close to 1 indicating highly efficient banks.

It is sufficient to point out that the profitability of the Bank is defined as $\left[\mathbf{e x p}\left(-\mathbf{U}_{\mathbf{i}}\right)\right]$. However, 


\section{Mll Macrothink}

International Journal of Accounting and Financial Reporting

ISSN 2162-3082

2015, Vol. 5, No. 2

as the user interface cannot really be observed, therefore it is estimated using notification conditional $\left[\exp \left(-\mathbf{U}_{\mathbf{i}} / \boldsymbol{\varepsilon}_{\mathbf{i}}\right]\right.$ as the best preacher of $U_{i t}$ at time $t$ (Hassan, 2006).

All models used to evaluate the performance of a company, including banks, seek to build a reference point or an appropriate frontier. In the economy, the main objective of business is maximizing the profit of their owners. That is why, the efficiency criteria are invariably destined for this rule. In principle, the rule is possible to realize in two ways:

First, profit efficiency is the ratio of current profits of the studied Bank and maximum profits that can be removed if the Bank was as efficient as the best bank in the sample. Unlike the cost efficiency, profit efficiency can be negative since firms can lose more than $100 \%$ of their substantial profits.

In addition, profit efficiency is generally wider than the cost efficiency to measure the performance of firms, the interest of the firm being more in the ability to improve its performance.

In this context, the profit efficiency is the broader concept of cost efficiency and income efficiency. It corresponds to the maximization of value and takes account of the errors on the outputs as well as inputs. It demands the same managerial attention granted to the increase in the marginal dollar of income as to reduce the marginal dollar cost while avoiding the misleading impressions that may result by focusing on costs or income only.

According to Humphrey and Pulley (1997), alternative profit efficiency incorporates the differences of power market between banks and their ability to exploit these differences.

The estimation of the alternative profit frontier considers this time above the amount of output as the dependent variable. In other words, prices of outputs are no longer considered as given and are therefore likely to vary. Such a framework is suitable for situations where banks have a degree of market power to influence prices.

The profit frontier is expressed as follows:

$$
\pi=\pi\left(\mathbf{p}, \mathbf{w}, \mathbf{u}_{\pi}, \mathbf{v}_{\pi}\right)
$$

- $\boldsymbol{\pi}$ : indicates the profit of the bank.

- $\mathbf{y}:$ the vector of quantities of outputs.

- $\mathbf{W}$ : the vector of inputs prices.

- $\mathbf{u}_{\mathrm{a} \pi}$ : the factor of inefficiency of profit.

- $\mathbf{V}_{\mathrm{a} \pi}$ : random errors.

In this case, the efficiency is measured by the difference between the profit of the studied Bank 
and the Bank with the best practices, and it is by fixing the quantities of outputs and not their prices.

Thus, let's take the example of a Bank B, the score of alternative profit efficiency is as follows:

$$
\operatorname{EFF} \pi_{B}=\pi^{B} / \pi^{\max }
$$

According to Berger and Mester (1997), the choice of this specification to frontier of efficiency is necessary when one of the following conditions exists:

-If banks are unable to fully control the scale of their production to achieve the desired size.

-If there is a substantial difference in the quality of banking services which must be taken into account.

-If the market structure is not perfectly competitive, and confer on banks a certain market power in determining the price.

-If the prices of the outputs are not measured properly thus the standard efficiency frontier would give bad results.

\section{2- Hypothesis: Bank's efficiency determinant}

After obtaining a measure of cost and profit efficiencies of Islamic banks, we check the determinant factors of bank's efficiency. Using panel data modeling, we test the internal factors to the Bank usually used in the analysis of the determinants of the efficiency of financial institutions: the size of the Bank, the capital adequacy ratio, profitability, credit, risk, and operational costs. For each determinant we have, a hypothesis taking into account results of previous studies

Hypothesis 1: Referring to the work of Haron (2004) and Srairi (2010) on Islamic banks and Papadopoulas (2004) and Pasiouras (2007) on conventional banks, we assume that banks with a high total asset are more efficient in terms of cost and profit before and during the financial crisis and less efficient after the crisis in terms of cost and profit.

Hypothesis 2: Previous studies (Bashir, 1999; Diamond and Rajan, 2001; Pereraet al., 2007; Ben Khediri and Ben-Hasan, 2009) show that banks with higher ratio of equity are more efficient in terms of cost and profit.

Hypothesis 3: Based on the research of Darrat et al. (2003) and Hassan (2006), we assume that banks with high ROAA ratio are more efficient in terms of cost and profit.

Hypothesis 4: Banks with high COIN ratio are more efficient in profit and less efficient in cost according to previous studies (Bashir, 2003; Hussein, 2003; Olson and Zoubi, 2011). 


\section{Mll Macrothink}

International Journal of Accounting and Financial Reporting

ISSN 2162-3082

2015, Vol. 5, No. 2

Hypothesis 5: According to Kamaruddinet al. (2008), Ben Khediri and Ben-Khedhiri (2009) and Srairi. S (2010), we assume that the higher operation costs of bank are, the less efficient the bank will be in terms of cost and profit.

\section{3- Data and sample}

We estimate the performance of Islamic banks using analysis of efficiency scores. We use a sample of 62 Islamic banks. The data used for our sample sourced from database BANKSCOPE BVD-IBCA (June, 2011) during the period from 2004 to 2010. Furthermore, these banks belong to six countries in the Southeast Asia region and 10 countries in the region MENA (Middle East and North Africa) including 5 countries of the GCC (Gulf Cooperation Council). This sample is chosen based on well-known banks in Islamic banking.

As the macroeconomic variables of the countries in the sample, our source was the International Financial Statistics. Given that the countries in the sample have different currencies; all annual financial values are converted into USD, through appropriate means of the exchange rate of each year.

\section{1- Outputs, prices of inputs, total cost, total profit}

According to the intermediation approach, banks consider the labor used, physical capital and financial capital as inputs and they are supposed to produce deposits and investment services. The dependent variables are:

TC: The total cost and $\Pi$ : total profit. In the profit function, the total cost is replaced by total profit $(\pi)$ to avoid differences in regimes of taxes between the countries in the sample.

The prices of the inputs are (Yi):

Y1: The price of labor (or labor costs). Some authors propose to measure the labor factor by the number of employees (Sassenou, 1999) or the number of employees in full-time equivalent (Wheelock and Wilson, 1999). The ratio of personal expenses to total asset seems unanimously the measure adopted to assess this input. Thus, we refer to Artunbas et al. (2000) as we will use an approximate measure of the price of work because of the lack of information on the number of employees.

Y2: The price of fund. Our sample includes only Islamic banks, so this ratio will be calculated by the profit expenses on each bank to total deposits.

Y3: Is the price of physical capital. Physical capital poses a problem of definition because of the specificity of the banking firm. It seems that the best-known measure in the literature assesses physical capital as the ratio of non-interest expenses (operation expenses) on the total fixed assets.

Referring to cost and profit models and the paper of Srairi (2010), we retain two outputs (Pi): P1: net total funding and P2: other earning assets. 


\section{2- Macroeconomic Variables}

To identify the common frontier, we include several macroeconomic variables in the estimation of the cost and profit functions. We use the same measures as in previous studies (Fries and Taci, 2005; Carvalo and Kasman, 2005; Pareraet al., 2007; Srairi, 2010):

The following table summarizes the variables used in this study:

Table 1: Description of Variables

\begin{tabular}{|c|c|c|}
\hline $\begin{array}{l}\text { Types of } \\
\text { variables }\end{array}$ & Notations & Definition \\
\hline \multirow{2}{*}{$\begin{array}{c}\text { Dependent } \\
\text { Variables }\end{array}$} & TC : Total cost & $\begin{array}{l}\text { Profit expenses }+ \text { Personnel expenses }+ \text { other operating } \\
\text { expenses. }\end{array}$ \\
\hline & $\pi:$ total profit & Total income $-\mathrm{TC}$ \\
\hline \multirow{3}{*}{ Price of inputs } & Y1 : price of labor & Personal expenses /total asset \\
\hline & Y2 : price of fund & Profit expenses / total deposits \\
\hline & Y3 : price of physical capital & Operating expenses / fixed assets \\
\hline \multirow{2}{*}{ Outputs } & P1 : net total funding & Financing granted to customers \\
\hline & P2 : other earning assets & Investment Bond + bond + certificate of deposit \\
\hline \multirow{5}{*}{$\begin{array}{l}\text { macroeconomic } \\
\text { Variables }\end{array}$} & CGDP : GDP per capita & GDP/ total population \\
\hline & DMON : degree of monetization & M2 (monetary reserves)/GDP \\
\hline & DDEM : density of the demand & Total deposit of the banking sector / area in $\mathrm{km}^{2}$ \\
\hline & INFR : annual average rate of inflation & $\left(\mathrm{CPI}_{\mathrm{t}}-\mathrm{CPI}_{\mathrm{t}-1}\right) / \mathrm{CPI}_{\mathrm{t}-1}$ \\
\hline & DPOP : population density & Number of inhabitants / area in $\mathrm{km}^{2}$ \\
\hline \multirow{5}{*}{$\begin{array}{l}\text { Determinants of } \\
\text { efficiency }\end{array}$} & $\log ($ Ass $):$ size & Logarithm of total assets \\
\hline & EQAS : capital adequacy & equity/ total assets \\
\hline & ROAA : profitability & Net Profit /average total assets \\
\hline & LOAS : credit risk & Total Loans/ total assets \\
\hline & COIN : operational costs & Costs/ incomes \\
\hline
\end{tabular}

\section{4- Empirical analysis}

\section{1- Descriptive statistics}

Table 2 shows that the average of total cost on total assets declined from 0.452 in 2004 to 0.050 in 2010 and it was unaffected by the 2007 crisis. This decrease can be explained by good management costs in Islamic banks (in our sample).

For the report of the total profit on total assets, it follows a growing curve and will be positive starting from 2007. This positive variation explains that the Bank begins to generate more profit during the crisis.

The decrease in the ratio of the financing granted to total assets (P1 / total assets) can be explained by diversification of Islamic banking activities.

As for the Labor costs, it drops in a continuous manner. This implies that the total asset is in continuous growth which may be due to the increase of the deposits collected by the Bank or 
the possession of more important amount of liquidity. No specific change is observed for this variable before or after the crisis.

Table 2:Descriptive statistics of the dependent variables, inputs and outputs

\begin{tabular}{|c|c|c|c|c|c|c|c|c|c|}
\hline \multirow{3}{*}{$\begin{array}{c}\text { depend and } \\
\text { independent } \\
\text { variables }\end{array}$} & & \multicolumn{7}{|c|}{ Years } & \multirow{3}{*}{$\begin{array}{l}\text { Total } \\
\text { Mean }\end{array}$} \\
\hline & & \multicolumn{3}{|c|}{ Pre-crisis } & \multicolumn{2}{|c|}{ Crisis } & \multicolumn{2}{|c|}{ Post-crisis } & \\
\hline & & 2004 & 2005 & 2006 & 2007 & 2008 & 2009 & 2010 & \\
\hline \multirow{4}{*}{$\begin{array}{l}\text { TC/tot } \\
\text { assets }\end{array}$} & Mean & 0.452 & 0.112 & 0.070 & 0.057 & 0.056 & 0.055 & 0.050 & 0.121 \\
\hline & Min & 0 & 0 & 0.018 & 0.0166 & 0.020 & 0.018 & 0.017 & 0 \\
\hline & Max & 18 & 2 & 0.319 & 0.102 & 0.123 & 0.106 & 0.108 & 18 \\
\hline & Std.D & 2.427 & 0.282 & 0.053 & 0.022 & 0.025 & 0.027 & 0.023 & 0.925 \\
\hline \multirow{4}{*}{$\begin{array}{l}\Pi \text { / tot } \\
\text { assets }\end{array}$} & Mean & -0.038 & -0.017 & -0.010 & 0.004 & 0.008 & 0.006 & 0.003 & -0.006 \\
\hline & Min & -2 & -0.590 & -0.2894 & -0.042 & -0.024 & -0.027 & -0.053 & -2 \\
\hline & Max & 0.350 & 0.072 & 0.046 & 0.075 & 0.067 & 0.037 & 0.034 & 0.350 \\
\hline & Std.D & 0.276 & 0.091 & 0.055 & 0.020 & 0.017 & 0.014 & 0.016 & 0.112 \\
\hline \multirow{4}{*}{$\begin{array}{l}\mathrm{P} 1 / \text { tot } \\
\text { assets }\end{array}$} & Mean & 7.596 & 0.702 & 0.004 & 0.004 & 0.569 & 0.560 & 0.556 & 1.574 \\
\hline & Min & 0 & 0 & 0.005 & 0.072 & 0.137 & 0.177 & 0.094 & 0 \\
\hline & Max & 379 & 5.241 & CTTC & 1.006 & 0.8225 & 0.830 & 1.141 & 379 \\
\hline & Std.D & 50.578 & 0.7136 & 0.315 & 0.195 & 0.142 & 0.166 & $0.2 \mathrm{~s}$ & 19.081 \\
\hline \multirow{4}{*}{$\begin{array}{l}\mathrm{P} 2 / \text { tot } \\
\text { assets }\end{array}$} & Mean & 0.275 & 0.586 & 0.350 & 0.295 & 0.003 & 0.258 & 0.171 & 0.333 \\
\hline & Min & 0 & 0 & 0.012 & 0.010 & 0.036 & 0.031 & 0.038 & 0 \\
\hline & Max & 2.868 & 9,214 & 0.867 & 0.843 & 0.670 & 0.005 & 0.775 & 9,214 \\
\hline & Std.D & 0.398 & 1.532 & 0.235 & 0.174 & 0.149 & 0.148 & 0.276 & 0.620 \\
\hline \multirow{4}{*}{ Y1 } & Mean & 0.030 & 0.027 & 0.014 & 0.013 & 0.012 & 0.011 & 0.011 & 0.017 \\
\hline & Min & 0 & 0 & 0.001 & 0.001 & 0.001 & 0 & 0 & 0 \\
\hline & Max & 0.625 & 0.735 & 0.045 & 0.043 & 0.036 & 0.038 & 0.032 & 0.735 \\
\hline & Std.D & 0.104 & 0.097 & 0.010 & 0.009 & 0.006 & 0.006 & 0.006 & 0.054 \\
\hline \multirow{4}{*}{ Y2 } & Mean & 0.060 & 1166 & 0.041 & 0.038 & 0.041 & 0.040 & 0.034 & $0.023 \mathrm{~s}$ \\
\hline & Min & 0 & 0 & 0.001 & 0.001 & 0.003 & 0.002 & 0.001 & 0 \\
\hline & Max & 1,354 & 63 & 0.1471 & 0.087 & 0.25 & 0.15 & 0.18 & 63 \\
\hline & Std.D & 0.170 & 8.413 & 0.027 & 0.021 & 0.036 & 0.029 & 0.025 & 3.173 \\
\hline
\end{tabular}

Descriptive statistics of macroeconomic variables are shown in table 3.

Since macroeconomic variables have different units of measure, there is a wide difference in values of the descriptive statistics of all these variables.

Firstly, GDP per capita (CGDP) has witnessed a continuous growth during the period of our study. From 2007, this variable (20000USD) is above the total average (17964.76 USD). The growth of this ratio leads us to measure the economic performance of a country that is the improvement of the standard of living which is not affected by the crisis of 2007.

The degree of monetization of the countries in our sample varies around the total mean (61.857\%). Only in 2007 and 2009, these countries had higher levels than the overall average. This ratio reflects the level of development of the financial sphere insofar as a low degree of 
monetization of the economy would be the result of a high level of sophistication of the financial system which allows individuals to hold less money.

As for the third macroeconomic variable, density of the demand, it is in continuous growth throughout the period of study. From the year 2007, the annual average begins to be higher than the total average reaching a peak in 2009.

For the inflation rates of the countries, the gap between the average rates in our sample is important it varies greatly between countries. Thus, these rates have averages higher than the total average in the years 2006,2007 and 2008. This variable influences the real economy in two specific areas: it affects the production and the economic efficiency. It is clear that the crisis started affecting the inflation rate of the countries in our sample since 2007.

There's also an important variation between the values of the population density that is not stable. This ratio has risen from $190,25 \mathrm{inhab} / \mathrm{km}^{2}$ in 2004 to $300,61 \mathrm{inhab} / \mathrm{km}^{2}$ in 2010 and starting to be above the total average since 2007.

Table 1: Descriptive statistics of macroeconomic variables by country

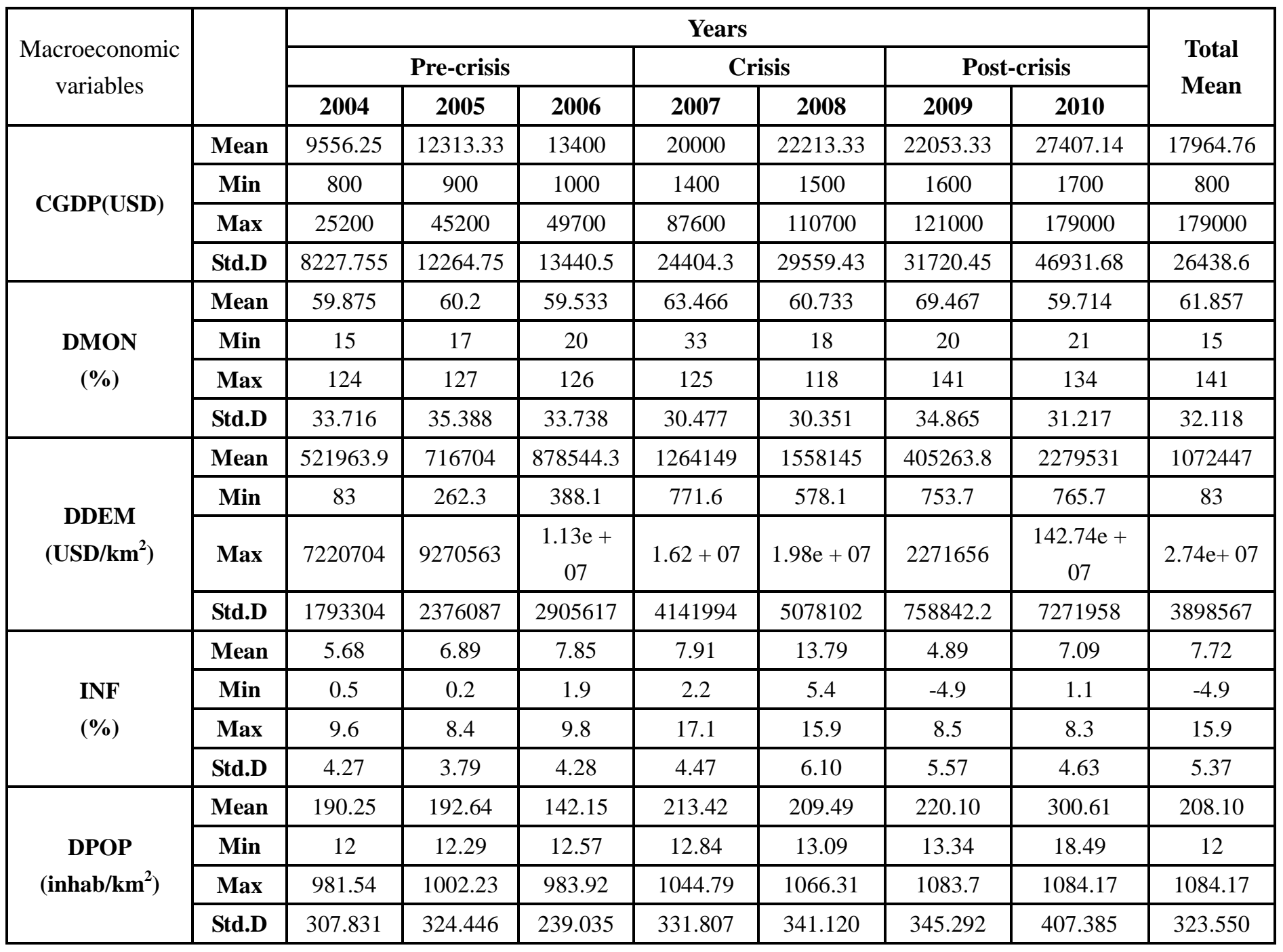




\section{2- Estimation of efficiency scores}

\subsection{1- The estimation of the results of cost and profit frontier}

Table 4 reports the parameters estimated on the basis of the stochastic translog frontier of cost and profit. In all, estimates show good results and the sign of most variables is consistent with our hypothesis.

First, on 26 regressions to estimate cost and profit efficiencies we have 16 regressions statistically significant for cost efficiency and 14 for profit efficiency. Secondly, the most important is that the estimated value of the cost and profit functions is valued respectively at-66.325 and - 526.640 and statistically significant at the $1 \%$ level. Thirdly, $\sigma^{2}$ is significant at a level of $1 \%$ to the cost function and $5 \%$ for the profit function and shows highly significant parameter estimates.

The table 4 shows a significant (at the level of 1\%) and positive relationship between output P1 (net total loans) coefficients and the two dependent variables (TC and $\pi$ ). This can be explained by the fact that a high output level generates a high total cost and an increase in profit. Similar results, especially for the cost function are reported by several recent studies (Lensink et al. 2008; Staikouras et al., 2008).

The coefficient $\alpha_{1}$ of the price of the funds of the cost function is significant which cannot explain that high input prices lead to higher costs. The elasticity of labor cost is less than the cost of funds. When prices are rising, banks must control more interest than personnel costs. The coefficients of the inputs in the profit function are all negative and significant as expected. This result is in agreement with the hypothesis which states that high prices undergo low profits. The terms of crossed outputs $\left(\alpha_{12}\right)$ coefficients are statistically significant. This result confirms the presence of economies of scope in the banks in our sample. The results also show that the time factor is not significant for the cost function except for the price of physical capital and other current assets. However, this function benefit coefficient is significant at the $1 \%$ level implying that the benefit of Islamic banks has improved over time.

Concerning macroeconomic variables, they also have an influence on the efficiency of Islamic banks. The results show that the level of economic development measured by GDP per capita is significant and negatively related to the profit of the Bank. Nevertheless, a good political action could encourage investment in creating a favorable environment. At the level of the strategies and actions to be implemented to stimulate the country's economic growth, the implementation of macroeconomic and structural Islamic policies integrating trade, fiscal and sectorial policies contribute to a stable environment for economic activity. Which can positively influences the efficiency of Islamic banks in these countries. It suggests that banks in countries with a high ratio of CGDP exhibit a level of higher profit than banks in countries with low incomes. These results follow those of Carvallo and Kasman (2005). However, Lensink (2008) found a negative relationship between CGDP and TC, indicating that the increase in GDP reduced costs.

The degree of monetization is not significantly related to the cost or profit. These results differ significantly from the study by Perera et al. (2007) who have found a positive and significant relationship between DMON ratio and the dependent variables (CT and profit).

For other elements of macroeconomic variables, our results for the effect of the DDEM are 
significant at the $1 \%$ level and are consistent to those of Carvallo and Kasman (2005) which show a negative impact of this variable on the total cost.

However, we find that the rate of inflation is not associated to the CT or $\pi$. It is because of inflation was largely moderate in our sample countries during the period 2004-2010. In his study on the profit efficiency in the banking industry, Koutsomanoli (2008) shows that the banks in countries with high levels of inflation have usually low profits. The results show also that the DPOP variable is significant in cost and profit functions.

Overall, the difference in the estimates of efficiency is affected by various factors, including the turbulent economic environment whereby Islamic banks have had to operate over the last decade and especially the financial crisis of 2007.

Table 4 : Estimates of the results of cost and profit frontier

\begin{tabular}{|c|c|c|c|c|c|}
\hline \multirow{2}{*}{ Parameters } & \multirow{2}{*}{ Notation } & \multicolumn{2}{|c|}{ Costefficiency } & \multicolumn{2}{c|}{ Profit Efficiency } \\
\cline { 3 - 6 } & & Coef & $\mathbf{Z}$ & Coef & $\mathbf{Z}$ \\
\hline$\alpha_{0}$ & Constant & -0.519 & -0.72 & -2.556 & -1.17 \\
\hline$\alpha_{1}$ & $\ln (\mathrm{y} 1)$ & 0.251 & $1.75^{*}$ & -1.478 & $-3.58^{* * *}$ \\
\hline$\alpha_{2}$ & $\ln (\mathrm{y} 2)$ & -0.179 & -1.41 & -0.839 & $-1.86^{*}$ \\
\hline$\alpha_{3}$ & $\ln (\mathrm{y} 3)$ & 0.091 & $5.59^{* * *}$ & 0.018 & 0.35 \\
\hline$\beta_{1}$ & $\ln (\mathrm{p} 1)$ & 0.887 & $8.23^{* * *}$ & 1.419 & $4.19^{* * *}$ \\
\hline$\beta_{2}$ & $\ln (\mathrm{p} 2)$ & 0.201 & $2.15^{* *}$ & 0.386 & 1.23 \\
\hline$\alpha_{11}$ & $\ln (\mathrm{y} 1) \ln (\mathrm{y} 1)$ & 0.115 & $3.49^{* * *}$ & 0.338 & $3.48^{* * *}$ \\
\hline$\alpha_{12}$ & $\ln (\mathrm{y} 1) \ln (\mathrm{y} 2)$ & 0.010 & 0.17 & -0.448 & $-2.45^{* *}$ \\
\hline$\alpha_{22}$ & $\ln (\mathrm{y} 2) \ln (\mathrm{y} 2)$ & -0.055 & $-3.83^{* * *}$ & 0.029 & 0.51 \\
\hline$\beta_{11}$ & $\ln (\mathrm{p} 1) \ln (\mathrm{p} 1)$ & 0.159 & $11.16^{* * *}$ & 0.199 & $4.88^{* * *}$ \\
\hline$\beta_{12}$ & $\ln (\mathrm{p} 1) \ln (\mathrm{p} 2)$ & -0.209 & $-8.05^{* * *}$ & -0.083 & -0.96 \\
\hline$\beta_{22}$ & $\ln (\mathrm{p} 2) \ln (\mathrm{p} 2)$ & 0.127 & $8.22^{* * *}$ & -0.070 & -1.19 \\
\hline$\phi_{11}$ & $\ln (\mathrm{y} 1) \ln (\mathrm{p} 1)$ & 0.037 & 1.60 & 0.446 & $6.35^{* * *}$ \\
\hline$\phi_{12}$ & $\ln (\mathrm{y} 1) \ln (\mathrm{p} 2)$ & 0.072 & $4.13^{* * *}$ & -0.040 & -0.72 \\
\hline$\phi_{21}$ & $\ln (\mathrm{y} 2) \ln (\mathrm{p} 1)$ & 0.114 & $8.91^{* * *}$ & 0.044 & 1.12 \\
\hline$\phi_{22}$ & $\ln (\mathrm{y} 2) \ln (\mathrm{p} 2)$ & -0.079 & $-6.35^{* * *}$ & 0.030 & 0.77 \\
\hline $1_{1}$ & $\mathrm{~T}$ & 0.093 & 1.12 & -1.312 & $-4.84^{* * *}$ \\
\hline $\mathrm{l}_{2}$ & $\mathrm{~T} * \mathrm{~T}$ & 0.001 & 0.07 & 0.026 & 0.81 \\
\hline$\lambda_{1}$ & $\mathrm{~T} * \ln (\mathrm{y} 1)$ & -0.001 & -0.07 & -0.120 & $-2.81^{* * *}$ \\
\hline$\lambda_{2}$ & $\mathrm{~T} * \ln (\mathrm{y} 2)$ & -0.006 & -0.56 & -0.118 & $-3.61^{* * *}$ \\
\hline$\psi_{1}$ & $\mathrm{~T} * \ln (\mathrm{p} 1)$ & -0.027 & $-3.11^{* * *}$ & 0.053 & $1.94^{*}$ \\
\hline$\psi_{2}$ & $\mathrm{~T} * \ln (\mathrm{p} 2)$ & 0.015 & $1.73^{*}$ & -0.017 & -0.64 \\
\hline$\rho_{1}$ & $\mathrm{CGDP}$ & 0.012 & 0.36 & -0.327 & $-3.00^{* * *}$ \\
\hline$\rho_{2}$ & $\mathrm{DMON}$ & -0.020 & -0.44 & 0.159 & 1.12 \\
\hline$\rho_{3}$ & $\mathrm{DDEM}$ & -0.043 & $-2.51^{* *}$ & 0.258 & $4.49^{* * *}$ \\
\hline$\rho_{4}$ & $\mathrm{INFR}$ & -0.001 & -0.03 & 0.101 & 1.21 \\
\hline$\rho_{5}$ & $\mathrm{DPOP}$ & 0.042 & $1.67 *$ & -0.462 & $-5.93^{* * *}$ \\
\hline $\ln \sigma_{\mathrm{u}}^{2}$ & & -2.664 & $-4.77 * * *$ & -0.385 & $-1.89 *$ \\
\hline $\ln \sigma_{\mathrm{v}}^{2}$ & & -2.840 & $-12.12^{* * *}$ & -0.902 & $-5.32^{* * *}$ \\
\hline & & & & 7 \\
\hline
\end{tabular}




\begin{tabular}{|c|c|c|c|c|}
\hline$\sigma^{2}$ & 0.128 & & 1.086 & \\
\hline MLM & -66.325 & & -526.640 & \\
\hline
\end{tabular}

\subsection{2- Average efficiency of banks per year}

Table 5 summarizes the average levels of cost and profit efficiency per year and per period for all the banks in our sample during the interval 2004-2010 estimated by the parametric approach SFA with trans log cost and profit functions.

The first result to be noted is the existence of a level of cost efficiency higher than profit efficiency. Therefore, it seems that Islamic banks in the region MENA and Southeast Asia are more efficient in the generation of profits rather than in control of costs. Our results corroborate those of previous studies (Kabir, 2006; Ben Khediri and Ben-Khedhiri, 2009; Srairi, 2010). Inter-temporal comparison of scores suggests that the average of efficiency cost increases from $81.49 \% \%$ in 2004 to $82.18 \%$ in 2010 , also for the values of the average of profit efficiency going from $83.32 \%$ in 2004 to $88.99 \%$ in 2010 . Hence, during the 7 years of our study, the level of cost efficiency scores increases by $1 \%$ and the profit efficiency increases by $5 \%$.

In fact, cost efficiency has reached its max (at the beginning of the crisis) in the year 2007 with a level $(82.91 \%)$ higher than the average score. After, this level of efficiency began to decline but remained above the average cost efficiency. We can explain this high level of cost efficiency by the fact that the value of the total cost on total assets is in steady decline during the study period. That is to say that the banks master well their total costs regardless of the economic situations of countries.

As for the profit efficiency, the results show that cost efficiency scores vary around the total average with only levels below the total average in the years 2008 and 2009.

Following the overall average, cost and profit efficiency scores are respectively $82.13 \%$ and $82.47 \%$ which implies that during the study period, on average, Islamic banks of countries of MENA and Southeast Asia could reduce their costs and improve their profits by almost $18 \%$ to be at the height of good banking practices which implies that they are very close to the frontier of efficiency and that we have not experienced a bullish period or a bearish period since values were very close to each other.

Several factors explain this result. First there are no dominant banks in the countries of our sample since they have almost the same size. Second diversification of Islamic financial products does not leave a monopoly power for these banks. In fact, the high degree of efficiency is a consequence of the increase in the quality of financial banking services which has led to improved revenues so high profit efficiency regardless of policies of the countries since Islamic banks sell products.

Table 5: Average Scores of cost/profit efficiency per year

\begin{tabular}{|c|c|c|c|c|}
\hline \multirow{2}{*}{ Period } & \multirow{2}{*}{ Year } & \multirow{2}{*}{$\begin{array}{c}\text { Number of } \\
\text { observations }\end{array}$} & Costefficiency scores (\%) & Profit efficiency scores (\%) \\
\cline { 3 - 5 } & & 46 & Mean & Mean \\
\hline \multirow{3}{*}{ Pre-crisis } & $\mathbf{2 0 0 4}$ & 51.49 & 83.32 \\
\cline { 2 - 5 } & $\mathbf{2 0 0 5}$ & 55 & 81.14 & 89.05 \\
\cline { 2 - 5 } & $\mathbf{2 0 0 6}$ & 56 & 81.77 & 85.84 \\
\hline Crise & $\mathbf{2 0 0 7}$ & 56 & 82.91 & 87.96 \\
\hline
\end{tabular}




\begin{tabular}{|c|c|c|c|c|}
\hline & $\mathbf{2 0 0 8}$ & 57 & 82.61 & 75.22 \\
\hline \multirow{3}{*}{ Post-crisis } & $\mathbf{2 0 0 9}$ & 50 & 82.74 & 65.50 \\
\cline { 2 - 5 } & $\mathbf{2 0 1 0}$ & 56 & 82.18 & 88.99 \\
\hline \multirow{2}{*}{ Total } & $\mathbf{2 0 0 4 - 2 0 1 0}$ & 376 & 82.13 & 82.47 \\
\hline
\end{tabular}

\subsection{3- Average efficiency of banks by country}

The comparison of scores of cost and profit efficiency by country (Table 6) reveals that the variation in the cost efficiency is not stable among the countries. Results show that the Egypt banks are the most efficient (85.99\%) followed by the banks of Sudan $(84.38 \%)$ and Iran banks $(84.33 \%)$. We can say that these banks are more efficient than others for two reasons. First they can offer the maximum of services with the minimum of resources and better control the technical aspects of banking production. Either because they better understand production factors markets or banking products.

Concerning Jordanian banks, they are less efficient in terms of cost with a score of $73.57 \%$ that is to say that these banks must reduce their costs by $27 \%$ to be at the level of best banking practices.

However, levels of profit efficiency show more variation between the countries, noting that only four countries in the sample (Bangladesh, Egypt, UAE and Yemen) have scores of efficiency profit below the average $(82.47 \%)$.

All countries in the sample have profit efficiency scores higher than cost efficiency except Bangladesh, Egypt and Yemen. These three countries control costs more than the generation of profits.

We can also observe that the most efficient Bank in terms of profit is not necessarily the most efficient in terms of cost and vice versa. Let us take for example, Bahrain banks ranked fifth in terms of cost efficiency and which are the first in the ranking of profit efficiency. Equally, Egyptian banks with the highest cost efficiency are ranked twelfth in terms of profit efficiency. By comparing our results with those of Srairi(2010), we note some differences. For example, in our study, Emirates banks are less efficient than other banks, while they occupy second place in the study of Srairi (2010). We believe that these differences are due to several reasons: First, our sample contains a large number of Islamic banks which are absent in the study of Srairi (2010) and this has probably a significant effect on the efficiency of banks, especially the GCC countries. Second, our study period covers a larger time interval.

Table 6: Average Scores of efficiency cost/profit per country

\begin{tabular}{|c|c|c|c|}
\hline \multirow{2}{*}{ Country } & \multirow{2}{*}{$\begin{array}{c}\text { Number of } \\
\text { observation }\end{array}$} & Scores of cost efficiency (\%) & Scores of profit efficiency (\%) \\
\cline { 3 - 4 } & 17 & Average & Average \\
\hline Saudi Arabia & 33 & 83.75 & 109.59 \\
\hline Bahrain & 31 & 83.83 & 92.38 \\
\hline Bangladesh & 13 & 82.83 & 68.35 \\
\hline Egypt & 20 & 85.99 & 80.45 \\
\hline Indonesia & & 78.96 & 82.21 \\
\hline
\end{tabular}




\begin{tabular}{|c|c|c|c|} 
Iran & 19 & 84.33 & 92.48 \\
\hline Jordan & 12 & 73.57 & 156.89 \\
\hline Kuwait & 19 & 84.16 & 89.93 \\
\hline Malaysia & 66 & 83.02 & 85.96 \\
\hline Pakistan & 37 & 111.87 & 39.00 \\
\hline Qatar & 11 & 87.36 & 82.92 \\
\hline Sudan & 19 & 84.38 & 89.16 \\
\hline Thailand & 6 & 117.59 & 82.88 \\
\hline Turkey & 26 & 83.58 & 91.17 \\
\hline UAE & 27 & 104.67 & 79.45 \\
\hline Yemen & 20 & 78.38 & 76.49 \\
\hline
\end{tabular}

\section{3- Regression of the determinants of efficiency}

In the empirical analysis, it remains to analyze the internal factors that may explain the differences in efficiency through banks. To do this, we have included in the equation (II.1) five banks-specific variables: size, the capital adequacy, profitability, credit risk and operational cost. We will use linear regression to determine what factors influence the level of efficiency for the considered period.

In literature, there are several methods for modeling the determinants of the efficiency of a bank. The linear regression model is often estimated by the method of maximum likelihood MML (common statistical method used to infer parameters from the probability distribution for a given sample). But there are other methods to estimate it, among which we can mention the method of ordinary least squares (OLS).

To do this, we use the method (OLS) for the regression of the determinants of efficiency because it is a method which allows minimizing the impact of experimental error "adding information" in the measurement process.

We estimate in the first place, the fixed effects and random effects models used to take into account the heterogeneity of data. Second, we proceed to Hausman test to check which effect is appropriate to each model. In other words, this test will distinguish between the random effects model and the fixed effects model.

Then, we proceed respectively to tests of normality of the errors, heteroscedasticity test and the test of autocorrelation of the errors for each model and for the three periods. If there is a problem at the level of one of the tests, we will go to the generalized least squares method. The following table shows the regression results of the determinants of the efficiency by the OLS method:

Table 7: Regression of the Determinants of the efficiency by the OLS method

\begin{tabular}{|c|c|c|c|c|c|c|c|c|c|c|c|c|c|}
\hline \multicolumn{2}{|c|}{$\begin{array}{c}\text { Independent } \\
\text { variables }\end{array}$} & \multicolumn{6}{|c|}{ Cost efficiency } & \multicolumn{6}{|c|}{ Profit Efficiency } \\
\hline \multirow{2}{*}{$\begin{array}{c}\text { Parame } \\
\text { ter }\end{array}$} & \multirow{2}{*}{ Notation } & \multicolumn{2}{|c|}{ Pre-crisis } & \multicolumn{2}{|c|}{ Crisis } & \multicolumn{2}{|c|}{ Post-crisis } & \multicolumn{2}{|c|}{ Pre-crisis } & \multicolumn{2}{|c|}{ Crisis } & \multicolumn{2}{|c|}{ Post-crisis } \\
\hline & & Coef & $\mathbf{Z}$ & Coef & $\mathbf{Z}$ & Coef & $\mathbf{Z}$ & Coef & $\mathbf{Z}$ & Coef & $\mathbf{Z}$ & Coef & $\mathbf{Z}$ \\
\hline$\alpha_{0}$ & Constant & 0.649 & $19.29 * * * *$ & 0.6199 & $19.78 * * *$ & 0.726 & $\begin{array}{c}18.62 * * \\
*\end{array}$ & -0.165 & -0.35 & -0.168 & -0.44 & -0 & -0.40 \\
\hline
\end{tabular}




\section{Macrothink}

International Journal of Accounting and Financial Reporting ISSN 2162-3082 2015, Vol. 5, No. 2

\begin{tabular}{|c|c|c|c|c|c|c|c|c|c|c|c|c|c|}
\hline$\omega_{1}$ & LogAssets & 0.080 & 4.63. & 0.085 & $4.26^{* * *}$ & 0.090 & $4.33^{* * *}$ & 0.6881 & $2.88^{* * *}$ & 0.69 & $3.12 * *$ & 0.700 & $3.01 * * *$ \\
\hline$\omega_{2}$ & EQAS & $\begin{array}{c}-0.00 \\
5\end{array}$ & -0.83 & -0.004 & -0.85 & -0.005 & -0.79 & 0.148 & $1.98^{* *}$ & 0.170 & $1.89 * *$ & 0.178 & $1.67 * *$ \\
\hline$\omega_{3}$ & ROAA & 0.005 & 1.58 & 0.005 & 1.40 & 0.101 & -1.25 & 0.069 & $1.74 * *$ & 0.068 & $1.79 * *$ & 0.070 & $1.68 * *$ \\
\hline$\omega_{4}$ & COIN & 0.022 & $3.06 * * *$ & 0.024 & $3.10^{* *}$ & 0.028 & $3.08 * * *$ & 1.76 & $4.09 * * *$ & 0.394 & $4.23 * * *$ & 0.352 & $4.28 * * *$ \\
\hline$\omega_{5}$ & LOAS & 0.001 & 0.12 & 0.002 & 0.15 & 0.015 & 0.30 & 0.089 & 1.31 & 0.097 & 1.39 & 0.099 & 1.48 \\
\hline
\end{tabular}

After regression of the determinants of the efficiency by the ordinary least squares (OLS) method, which assumes a normal distribution and homoscedastic of the residue and the dependent variable, we perform tests outlined previously for the three periods.

For the cost efficiency model, the Hausman test gives a probability of 0.9973 (respectively 0.9900 and 0.9835 ) which is greater than $5 \%$. This means that it is a model with variable effects for the entire period of study. The results show the existence of problems of normality of residuals and autocorrelation of the errors before, during and after the crisis since the probabilities obtained for these tests are below the threshold of $5 \%$.

The profit efficiency is a random effects model according to the Hausman test since it has a probability of $0.9394>5 \%$ during the pre-crisis (respectively 0.9305 crisis and 0.9865 post-crisis). The Ramsey-Reset and normality tests prove the presence of the problems for the 3 phases of the studies. Probabilities given by the tests confirm the hypothesis of the absence of heterosedasticity of the errors.

After performing various tests and having detected the problems inherent in each model for each period, we opt for the generalized least squares regression method (GLS).

Table 8: Regression of the Determinants of the efficiency by the GLS method

\begin{tabular}{|c|c|c|c|c|c|c|c|c|c|c|c|c|c|}
\hline \multicolumn{2}{|c|}{$\begin{array}{c}\text { Variables } \\
\text { indépendantes }\end{array}$} & \multicolumn{6}{|c|}{ Cost efficiency } & \multicolumn{6}{|c|}{ Profitefficiency } \\
\hline \multirow[b]{2}{*}{ Paramètre } & \multirow[b]{2}{*}{ Notation } & \multicolumn{2}{|c|}{ Pre-crisis } & \multicolumn{2}{|c|}{ Crisis } & \multicolumn{2}{|c|}{ Post crisis } & \multicolumn{2}{|c|}{ Pre-crisis } & \multicolumn{2}{|c|}{ Crisis } & \multicolumn{2}{|c|}{ Post crisis } \\
\hline & & Coef & $\mathbf{z}$ & Coef & $\mathbf{z}$ & Coef & $\mathbf{Z}$ & Coef & $\mathbf{Z}$ & Coef & $\mathbf{z}$ & Coef & $\mathbf{z}$ \\
\hline$\alpha_{0}$ & Constant & 0.649 & $19.47 * * *$ & 0.623 & $19.82 * * *$ & 0.726 & $18.62 * * *$ & -0.165 & -0.37 & -0.168 & -0.42 & -0.180 & -0.48 \\
\hline$\omega_{1}$ & LogAssets & 0.080 & $4.67 * * *$ & 0.085 & $4.28 * * *$ & 0.090 & $4.33 * * *$ & 0.686 & $3.01 * * *$ & 0.698 & $3.08 * *$ & 0.700 & $3.06^{* * * *}$ \\
\hline$\omega_{2}$ & EQAS & -0.005 & -0.84 & -0.004 & -0.87 & -0.005 & -0.79 & 0.148 & $1.99 * *$ & 0.170 & $1.88^{*}$ & 0.178 & $1.75^{*}$ \\
\hline$\omega_{3}$ & ROAA & 0.005 & 1.60 & 0.005 & 1.45 & 0.101 & -1.25 & 0.069 & $1.73^{*}$ & 0.068 & $1.74 * *$ & 0.070 & $1.72 * *$ \\
\hline$\omega_{4}$ & COIN & 0.022 & $3.09 * * *$ & 0.024 & $3.15^{* *}$ & 0.028 & $3.08 * * *$ & 0.384 & $4.09 * * *$ & 0.394 & $4.12 * * *$ & 0.405 & $4.25 * * *$ \\
\hline$\omega_{5}$ & LOAS & 0.001 & 0.12 & 0.002 & 0.18 & 0.015 & 0.30 & 0.089 & 1.30 & 0.097 & 1.32 & 0.099 & 1.45 \\
\hline
\end{tabular}

We note in table 8 that the coefficient of $\log$ Assets 0.080 (respectively 0.085 and 0.090 ) is positively linked and statistically significant at the $1 \%$ level of cost efficiency scores. This result shows that the size of the banks has a positive impact on cost efficiency for the three sub period (before, during and after the crisis) which means that the banks having a higher total asset are the most efficient. Our result is consistent with several studies on Islamic banks (Haron, 2004; Srairi, 2010) and others on the conventional banks (Papadopoulas, 2004; 
Pasiouras, 2007).

Thus, large-sized banks tend to be closer to the efficient frontier than small ones. These banks can increase their returns to scale by the allocation of fixed costs on a high volume of services. With regard to profit efficiency, we can conclude from the results of the regression that there is a positive effect of size on profit efficiency. Coefficients are significant at the level of $1 \%$ forthe pre-crisis and post-crisis periods. For the crisis period, results show significance at the level of $5 \%$. It is therefore possible that Islamic banks in our sample are actually in a situation of increasing returns of scale i.e. they exploit all of the economies of scale.

Therefore the hypothesis of departure $\mathrm{H} 1$ is confirmed: An increase in the total assets of the bank is associated with an increase in cost and profit efficiency.

The capital adequacy ratio (EQAS) has a non-significant impact on cost efficiency. We can say that this ratio is not a determinant of cost efficiency for the three periods of study. On the other hand, it has a positive and statistically significant impact on the level of 5\% on the profit efficiency in pre-crisis period and on the level of $10 \%$ in pre-crisis and crisis periods. This confirms the hypothesis which States that well-capitalized banks are more efficient than their less-capitalized counterparts, in terms of profit efficiency. Our results are in accord with those of Bashir (1999), Diamond and Rajan (2001), Perera et al. (2007) and Ben Khediri and Ben-Khedhiri(2009) for samples of Islamic banks.

To cope with the volatility of deposits and to avoid the problem of liquidity, Islamic banks seek to ensure raising fund through the maintenance of a high ratio of equity to total assets. In keeping with Islamic finance standards, these banks make recourse to their own funds rather than external financing. Thus, their financing costs will fall while boosting profitability.

This positive relationship can also be explained by good governance of Islamic banks especially through the principle of sharing profits and losses. In summary, capitalized assets banks are considering low funding costs and subsequently high profits.

However, Results of Wahyu et al. (2012) (for Islamic banks)and others such as Staikouraset al. (2008) and Vanhoose (2007) (for conventional banks) report a negative relationship between the ratio of capitalization and profit efficiency. As a result, our hypothesis $\mathrm{H} 2$ is not checked because the banks with high capitalization ratios are more efficient in terms of profit while this relationship is not checked for cost efficiency.

With regards to the effect of ROAA, the result of the regression shows a non-significant coefficient of 0.005 for cost efficiency during pre-crisis period which leads us to say that this variable cannot be a determinant of the cost efficiency of Islamic banks. Similarly for the other two periods i.e. the ROAA variable cannot be a determinant of efficiency cost at any time.

The hypothesis that the ROAA ratio is positively correlated to the profit efficiency is validated for the three periods with a level of significance of $5 \%$ and $10 \%$. This result confirms the studies of Darrat and al. (2003) and Hassan (2006) who have found that this ratio is one of the determinants of the profit efficiency of Islamic banks. Our result can be explained by the use of Islamic banks to financing medium and long term source of significant income. 


\section{Mll Macrothink}

International Journal of Accounting and Financial Reporting

ISSN 2162-3082

2015, Vol. 5, No. 2

Hence, the hypothesis H3is not validated since we did not find a conclusive relationship between profitability and cost efficiency.

We note that operational cost (COIN) is positively correlated and statistically significant at cost and profit efficiency. For cost efficiency, coefficients are significant at the level of $1 \%$ for two sub periods pre-crisis and post-crisis. This ratio is also positively correlated to the cost efficiency at a level of $5 \%$ for the period of crisis. For profit efficiency, operational cost is positively correlated (for the three sub periods coefficient are statistically significant at the $1 \%$ level).

Our result can be explained by previous results (level of cost efficiency scores) showing a sound management of cost within Islamic banks and by the adoption of the strict policies of provisions for non-performing financing by Islamic banks. According to Kamaruddin et al. (2008), a high cost on income ratio is due to a very motivating remuneration of staff policy, heavy overhead costs and promotion in marketing activities to strengthen their balance sheets. This result has not been confirmed by Srairi (2010) showing that this ratio has a negative impact on the cost efficiency.

For profit efficiency, our result implies that banks with high cost reports have high levels of profit efficiency. In light of the risks faced by Islamic banks in financing activities, this result can be explained by the requirement of large profit margins in financing transactions, which will generate significant profits. Our results do not corroborate those of Srairi (2010) Ben Khediri et al. (2009) for conventional banks and those of Carvallo and Kasman (2005) and Ariff and Can (2008) for Islamic Banks. Therefore, hypothesis H4 is invalidated.

Finally, the coefficient measuring the risk of credit LOAS is not significant for both the cost and profit efficiency. Therefore, we cannot conclude that banks that take more risk are more efficient in terms of cost in crisis period or not. Therefore the hypothesis 5 is not validated.

To sum up, we can conclude that most of the estimated cost efficiency scores can be explained by specific factors of banks because only two hypotheses have been validated, while for profit efficiency, only one is rejected.

\section{5- Conclusion}

In this study, we first calculated the scores of efficiency of banks-specific factors and macroeconomic variables in 16 countries before, during and after the 2008 financial crisis. Then, we used five factors (total assets, capital adequacy, profitability, credit risk, operational costs) identified econometric regression test. The calculation was made in two parts: a model for cost efficiency and another for profit efficiency.

For the cost efficiency model, which is a random effects model for the three periods, the regression results showed that banks with a high total asset and high operation cost are the most efficient in terms of cost. With regard to the profit efficiency model, random effects are also preferred to fixed-effects.

On the evolution of efficiency scores, results on the panel data suggest that banks in our sample have a medium level of cost efficiency of $82.13 \%$ and an average score of profit efficiency of $82.47 \%$. Thus, if banks use the inputs available in an efficient way, they can reduce production costs and increases their profit by about $18 \%$ while maintaining the same level of production. 


\section{Mll Macrothink}

International Journal of Accounting and Financial Reporting ISSN 2162-3082 2015, Vol. 5, No. 2

That shows that banks have not arrived to maximize their outputs taking into account the available inputs.

We notice that the variable log Assets constitutes a determinant of cost efficiency. In addition, it has a positive impact on cost efficiency before, during and after the crisis. For profit efficiency, we can conclude from the results of the regression that there is a positive effect of size on the profit efficiency significant at $1 \%$ for the periods of pre-crisis and post-crisis and at the level of $5 \%$ for the period of crisis.

The capital adequacy ratio (EQAS) is not a determinant of cost efficiency for three periods of study. On the other hand, it has a positive and statistically significant impact on the level of 5\% on the profit efficiency in pre-crisis period and the level of $10 \%$ in pre-crisis and crisis periods. So there is only a determinant of profit efficiency.

With regards to the effect of ROAA, the result of the regression shows a non-significant coefficient for the cost efficiency for the period pre-crisis which leads us to say that this variable cannot be a determinant of the cost efficiency of Islamic banks. Similarly for the other two periods i.e. the ROAA variable cannot be a determinant of efficiency cost in any period. On the other hand, this ratio is a determinant of efficiency for the three periods with a level of $5 \%$ and $10 \%$.

With regard to the last two ratios, In respect of the operational cost (COIN), it is a determinant of the cost and profit efficiency with a positive impact for both types of efficiency. As to the risk of credit LOAS, it has no significant impact to cost and profit efficiency scores so it is neither a determinant for the cost nor for the profit efficiency during the three periods of study.

\section{Bibliography}

Abid A. Burki and Shabbir Ahmad. (2011). The Impact of Bank Governance on Bank Performance in Pakistan.The Lahore Journal of Economics, $\mathrm{n}^{\circ}$ 16:271-300.

Al-Jarrah I, Molyneux P. (2003). Efficiency in Arabian Banking. Jordan Journal of Business Administration, $\mathrm{n}^{\circ} 3$ : 373-390.

Ariff M and Can L. (2008). Cost and profit efficiency of Chinese banks: A non-parametric analysis. China Economic Review, $n^{\circ}$ 19:260-273.

Bashir, M. (1999). Risk and profitability measures in Islamic banks: The case of two Sudanese banks. Islamic Economic Studies, vol 6, n²: 1-24.

Bashir M. (2003). Determinants of Profitability in Islamic Banks: Some Evidence from the Middle East, vol 11, $\mathrm{n}^{\circ} 1: 31-57$.

Battese $G$ and Coelli, T. (1995). Model for technical inefficiency effects in stochastic frontier production function for panel data. Empirical Economics, vol20, $\mathrm{n}^{\circ} 2: 325-32$.

Ben Khediri K and Ben-Khedhiri H. (2009). Determinants of Islamic Bank Profitability in the MENA Region. International Journal of Monetary Economics and Finance, vol 2, n 3/4: 409-426.

Berger A and Humphrey D. (1997): efficiency of financial institutions: international survey and direction for future research. European journal of operational research, vol 21: 175-212. 
Berger A and Mester L. 1997. Inside the black box: What explains differences in the efficiency of financial institutions. Journal of Banking and Finance, vol 2, nº7: 895-947.

Carvallo O and Kasman A. (2005). Cost efficiency in the Latin American and Caribbean banking systems. International Finance MarketsInst Money, vol 15 : 55-72.

Coelli T (1996) A guide to frontier version 4.1: A computer program for stochastic frontier production and cost function estimation.Working Paper 96/07. Centre for Efficiency and Productivity Analysis, Univ. of New England, Armidale, Australia.

Darrat A.F, Topuz C, Youssef T (2003) Assessing cost and technical efficiency of banks in Kuwait. Paper presented in the ERF 8th annual conference in Egypt.

Debreu G (1951). The coefficient of Resource Utilisation. Econometrica, vol 19, $\mathrm{n}^{\circ} 3$ : 273-292.

Dietsch. M, Weill. L. (1997). The performance of deposits French banks: an assessment by the DEA, working paper method.

Douglas W. Diamond and Raghuram G Rajah. (2001). Banks, short-term debt and financial crises: theory, policy implications and applications. Carnegie-Rochester Conference Series on Public Policy, $n^{\circ} 54$ : 37-71.

Farrell M. J. (1957). The measurement of productive efficiency, Journal of the Royal statistical society, vol 120, 3: 253-281.

Fries S and Taci A. (2005) Cost efficiency of banks in transition: evidence from 289 banks in 15 post-communist countries. Journal of Banking and Finance, vol 29, $\mathrm{n}^{\circ}$ 1:55-81.

Greene W. (1980). On the estimation of a flexible frontier production model. Journal Econometrics, vol 13: 101-115.

Haron, Sudin (2004), Determinants of Islamic Bank Profitability, The Global Journal of Finance and Economics, vol 1, n¹:49-64.

Hassan M.K and Hussein K.A. (2003), Static and dynamic efficiency in the Sudanese banking system, Review of Islamic Economics, Vol. 14:5-48.

Hassan, M.K. and Bashir AH. M. (2003). Determinants of Islamic banking profitability. Proceedings of the Economic Research Forum (ERF) 10th Annual Conference, Marrakesh, Morocco, 16-18 December, 2003.

Hassan M and Isik I. (2002). Technical scale and allocative efficiencies of Turkish banking industry. Journal of Banking and Finance, vol 26, n 4:719-766.

Hassan M. 2005. The cost, profit and X-efficiency of Islamic banks. Paper presented at the Economic Research Forum 12th annual conference, Cairo, Egypt.

Humphrey D, Pulley L. (1997). Bank's responses to deregulation: profit, technology and efficiency. Journal of Money Credit and Banking, vol 29, ${ }^{\circ}{ }^{\circ}$ : 73-93.

Hussein, K.A. (2003), Operational Efficiency in Islamic banking: the Sudanese experience, Working Paper $\mathrm{n}^{\circ} 1$, Islamic Research and Training Institute (IRTI), Islamic Development Bank, Jeddah, Saudi Arabia.

James O and Svein B. (2012).A meta-analysis of DEA and SFA studies of the technical efficiency of seaports: A comparison of fixed and random-effects regression models. Transportation Research Part A, $\mathrm{n}^{\circ} 46: 1574-1585$.

Kabir Hassan. M. (2006). The X-Efficiency in Islamic Banks. Islamic Economics Studies, vol 13, n²: 49-78. 
Kamaruddin B, Safa M and Mohd R. (2008). Assessing production efficiency of Islamic banks and conventional bank Islamic windows in Malaysia. International Journal of Business and Management Research, $\mathrm{n}^{\circ}$ 1:31-48.

Koutsomanoli-Filippaki A, Mamatzakis E and Staikouras C. (2009). Structural reforms and banking efficiency in the new EU States. Journal of Policy Model, vol 31, n 9: 17-21.

Lensink R, Meesters A and Naaborg I. (2008): bank efficiency and foreign ownership: do good institutions mater? Journal of Banking and Finance, vol32 :834-844.

Mamatzakis E, Staikouras C and Koutsomanoli-Filippaki A. (2008).Bank efficiency in the new European Union member states: is there convergence. International Review of Financial Analysis, vol 17, n5: 1156-1172.

Mariani A M, David S S and Giuliana B. (2011). Efficiency and total factor productivity change of Malaysian commercial banks. The Service Industries Journal, vol 31, $\mathrm{n}^{\circ} 13$ : 2117-2143.

Michael K and Aljar M (2013). Effects of specification choices on efficiency in DEA and SFA. Efficiency and Productivity Growth: Modelling in the Financial Services Industry, First Edition. Edited by FotiosPasiouras.

Mohamed, K.S. and Molyneux, P. (2003). Are GCC banks efficient?, communication to the economic research forum.

Olson D and Zoubi T. (2008). Using accounting ratios to distinguish between Islamic and conventional banks in the GCC region. International Journal of Accounting, vol 43, $\mathrm{n}^{\circ} 1$ : 45-65.

Olson D and Zoubi T. (2011). Efficiency and bank profitability in MENA countries. Emerging Markets review, vol 12, $\mathrm{n}^{\circ}$ 2: 94-110.

Papadopoulos S. (2004). Market structure performance and efficiency in European banking. International Journal of commerce and Management, vol 14, $\mathrm{n}^{\circ}$ 1: 79-100.

Pasiouras F. (2007). Estimating the technical and scale efficiency of Greek commercial banks: the impact of credit risk off-balance sheet activities, and international operation. Research in International business and finance, vol 22, $\mathrm{n}^{\circ} 3: 301-318$.

Pulley L B and Humphrey D B. (1993). The role of fixed costs complementarities in determining scope economies and the cost of narrow banking proposals, Journal of business, vol 66, n³: 437-462.

Samir Srairi. (2010). Cost and profit efficiency of conventional and Islamic banks in GCC countries. Journal of Productivity Analysis, vol 34, $\mathrm{n}^{\circ}$ 1: 45-62.

Staikouras C, Mamatzakis E and Koutsomanoli-Filippaki A. (2008). Cost efficiency of the banking industry in the South Eastern European region. Journal of International Financial Markets Institutions and Money, vol 18, n5: 483-497.

Vanhoose D. (2007). Theories of behavior under bank capital regulation. Journal of Banking and Finance, vol 31, $\mathrm{n}^{\circ} 12: 3680-3697$.

Wheelock D C and Wilson P W. (1999). Technical progress inefficiency and productivity changes a US banking 1984-1993, Journal of money, credit and banking, vol 31, $\mathrm{n}^{\circ} 2$ : 212-234. 


\section{Ml Macrothink}

International Journal of Accounting and Financial Reporting

ISSN 2162-3082 2015, Vol. 5, No. 2

Yildirim, H.S., Philippatos, G.C., 2007. Efficiency of banks: Recent evidence from the transition economies of Europe, 1993-2000. European Journal of Finance,vol 13, $\mathrm{n}^{\circ} 2$ : 123-143.

Zarrouk.H (2012). Does Financial Crisis Reduce Islamic Banks' Performance? Evidence from GCC Countries Journal of Islamic Finance and Business Research, vol 1, n²1:1-16. 